\title{
ЕФЕКТИВНІСТЬ ВИКОРИСТАННЯ ІНГІБІТОРІВ АЛЬФА-ГЛЮКОЗИДАЗИ У ХВОРИХ НА ЦУКРОВИЙ ДІАБЕТ 2 ТИПУ, УСКЛАДНЕНОГО ДІАБЕТИЧНОЮ СТОПОЮ
}

\author{
І. О. Беркела, Л. В. Наумова, І. М. Ястремська \\ Рахівська центральна районна лікарня \\ ДВНЗ «Тернопільський державний медичний університет \\ імені І. Я. Горбачевського МОЗ Украӥни»
}

\begin{abstract}
У статті наведено результати дослідження впливу інгібіторів альфа-глюкозидази на основні показники вуглеводного обміну та динаміку маси тіла у пацієнтів на цукровий діабет 2 типу, ускладнений діабетичною стопою. Автори вказують на позитивний ефект препаратів цієї групи на всі компоненти метаболічного синдрому, безпеку для організму, відсутність серйозних протипоказань і низький рівень розвитку гіпоглікемій. Воглібоз як представник групи інгібіторів альфа-глюкозидази може ефективно використовуватися у поєднанні з інсулінотерапією.
\end{abstract}

\section{THE EFFICIENCY OF INHIBITORS OF ALPHA-GLUCOSIDASE IN PATIENTS WITH DIABETES MELLITUS TYPE 2 COMPLICATED WITH DIABETIC FOOT}

\author{
I. O. Berkela, L. V. Naumova, I. M. Yastremska \\ Rakhiv Central District Hospital \\ I. Horbachevsky Ternopil State Medical University
}

\begin{abstract}
The article presents the results of research of influence of inhibitors of $\alpha$-glucosidase on the basic parameters of carbohydrate metabolism and the dynamics of body weight in patients with diabetes mellitus type 2 complicated with diabetic foot. The authors note the positive effect of these drugs on all components of the metabolic syndrome, safe for body, no serious contraindications and low level of development of hypoglycemia. Voglis as a representative of the group of inhibitors of $\alpha$-glucosidase can be effectively used in combination with insulin therapy.
\end{abstract}

Вступ. Відповідно до даних світової статистики, кожні 13-15 років кількість людей, які страждають від цукрового діабету (ЦД) подвоюється. Аналогічна тенденція спостерігається і в Україні - показник захворюваності збільшився з 115,6 у 1993 р. до 267,0 у 2012 р. на 100 тис. населення; показник поширеності, відповідно, з 699,2 до 2885,0 (МОЗ України, 2013) [6].

ЦД вважається найбільш драматичною сторінкою сучасної медицини, оскільки йому притаманна рання інвалідизація і висока смертність від ускладнень $[5,6]$. Одним з хронічних ускладнень ЦД 2 типу $\epsilon$ діабетична стопа, яка часто $€$ першим проявом даного захворювання, що призводить не лише до зниження працездатності, а й до інвалідизації пацієнтів. Саме діабетична стопа $є$ однією з головних причин ампутацій нижніх кінцівок. Власне тому пошук нових, комбінованих методів лікування з метою компен-

(С) І. О. Беркела, Л. В. Наумова, І. М. Ястремська, 2016 сації вуглеводного обміну залишається достатньо актуальним.

Загальновизнано, що при призначенні терапії ЦД 2 типу найкращим є вибір препаратів, що не виснажують функцію бета-клітин, сприяють зниженню маси тіла (або принаймні не підвищують їі), мають мінімальний ризик розвитку гіпоглікемій.

Однією з груп пероральних цукрознижувальних, включених в Уніфікований клінічний протокол первинної та вторинної (спеціалізованої) медичної допомоги при цукровому діабеті 2 типу, затверджений наказом Міністерства охорони здоров'я від 21.12.2012 р. № 1118, є інгібітори альфа-глюкозидази. Це група препаратів, що запобігають засвоєнню складних вуглеводів у кишечнику і таким чином вирівнюють відхилення рівня глюкози в крові після споживання їжі [1]. Одні з перших представників інгібіторів альфа-глюкозидази не використовуються внаслідок 
вираженості побічних ефектів, низької ефективності та високої вартості.

Механізм дії інгібіторів альфа-глюкозидази полягає в конкуренції з полісахаридами за місця зв'язування на відповідних ферментах шлунково-кишкового тракту. Наслідком такої конкуренції $є$ уповільнення темпів вивільнення глюкози зі складних вуглеводів і, відповідно, її всмоктування в кров із подальшим зниженням рівня постпрандіальної гіперглікемії. Таким чином, ця група препаратів найбільш ефективна у випадку високої постпрандіальної глікемії $[3,6]$.

Результати дослідження STOP-NIDDM trial свідчать і про те, що частота серцево-судинних захворювань, зокрема інфаркту міокарда (IM), значно нижча в групі, у якій призначено інгібітори альфа-глюкозидази, порівняно з плацебо.

Метааналіз семи довгострокових досліджень також показав, що на тлі приймання інгібіторів альфа-глюкозидази покращується глікемічний контроль, знижується рівень тригліцеридів, маса тіла і систолічний артеріальний тиск. Ці спостереження показують, що профілактика постпрандіальної гіперглікемії $\epsilon$ перспективною терапевтичною стратегією для зниження ризику виникнення ЦД, артеріальної гіпертензії, дисліпідемії, ожиріння і серцево-судинних захворювань у пацієнтів із метаболічним синдромом $[5,6]$.

Відомо, що побічним ефектом певних груп цукрознижувальних препаратів $є$ збільшення маси тіла. Здатність інгібіторів альфа-глюкозидази знижувати масу тіла в пацієнтів має дуже велике значення, оскільки боротьба з ожирінням та надмірною масою тіла $\epsilon$ одним з основних завдань при лікуванні ЦД 2 типу [5]. Доведено значне зниження індексу маси тіла й окружності талії протягом трьох років [4-6].

Крім того, інгібітори альфа-глюкозидази абсолютно безпечні для пацієнтів навіть при тривалому застосуванні й практично не мають серйозних протипоказань. Вони не всмоктуються у кров, діють винятково у шлунково-кишковому тракті без системного токсичного впливу. Єдиними побічними ефектами інгібіторів альфа-глюкозидази є метеоризм і дискомфорт у шлунково-кишковому тракті, що в багатьох випадках призводить до відмови від його застосування [5].

Одним із представників даної групи є воглібоз. Його можна застосовувати як у монотерапії, так і в комбінації з іншими таблетованими цукрознижувальними препаратами чи інсуліном. Воглібоз довів свою ефективність щодо покращення всіх показників вуглеводного обміну, спостерігалося зменшення інсу- лінорезистентності та маси тіла. До того ж препарат покращує ліпідний спектр крові, зокрема вірогідно знижує рівень тригліцеридів [6]. На ринку України воглібоз представлений препаратом «Воксид» у дозуванні 0,2 і 0,3 мг.

Метою роботи було визначення впливу воглібозу на масу тіла, постпрандіальну глікемію, глікований гемоглобін у пацієнтів із ЦД 2 типу, ускладненим діабетичною стопою.

Основна частина. У дослідженні взяли участь 32 хворих на ЦД 2 типу, ускладнений діабетичною стопою. Спостереження за кожним із пацієнтів тривало 12 тижнів. Їх було поділено на дві групи. До І групи увійшло 18 пацієнтів (10 жінок і 8 чоловіків) із ЦД 2 типу, ускладненим діабетичною стопою, які отримували інсулінотерапію (4 хворих отримували генсулін Р і H, 2 - актрапід НМ і протафан НM, 5 - фармасулін Н та HNP, 2 - інсуман базал та рапід, 3 - фармасулін HNP, 2 - інсуман комб 25 ). До II групи увійшло 14 хворих із ЦД 2 типу, ускладненим діабетичною стопою, які отримували інсулінотерапію (5 хворих отримували генсулін Р і H, 2 - фармасулін Н та HNP, 2 - інсуман базал та рапід, 3 - фармасулін HNP, 2 - інсуман комб ${ }_{25}$ ). Середній вік

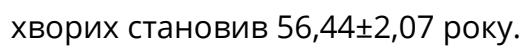

Крім того, досліджували антропометричні дані (маса тіла та індекс маси тіла), постпрандіальну глікемію та глікований гемоглобін (HbAlc).

Отримані результати статистично оброблені з визначенням середніх показників $(\mathrm{M} \pm \mathrm{m})$ та вірогідності за критерієм Стьюдента.

У І групі обстежуваних (пацієнти з ЦД 2 типу з синдромом діабетичної стопи), які отримували лікування лише інсуліном, спостерігали зниження постпрандіальної глікемії та незначне зниження глікованого гемоглобіну (табл. 1). На масу тіла, індекс маси тіла дане лікування мало нейтральний вплив, а у 7 пацієнтів призвело до збільшення маси тіла.

У II групі хворих, які, крім інсулінотерапії, отримували ще препарат «Воглібоз» у дозуванні 0,2 мг на добу, спостерігали тенденцію до зниження маси тіла та IMT (табл. 2). Крім того, встановлено вірогідне зниження постпрандіальної глікемії через 2 год після споживання їжі на 1,94 ммоль/л.

Побічні ефекти препарату були транзиторними і зникали через 2 тижні після приймання препарату, коли організм повністю адаптувався до нього. Найчастіше хворі скаржилися на здуття живота (82 \%), проноси (46\%), нудоту (28\%). Жоден із пацієнтів не відмовився від подальшого лікування через побічні 
Таблиця 1. Динаміка досліджуваних показників із ЦД 2 типу з синдромом діабетичної стопи, які отримують інсулінотерапію

\begin{tabular}{|l|c|c|c|}
\hline \multicolumn{1}{|c|}{ Показник } & На початку дослідження & Через 12 тижнів & 3міни \\
\hline Маса тіла, кг & $95,00 \pm 3,20$ & $94,83 \pm 3,10$ & $-0,07$ \\
\hline IMT, кг/м & $33,17 \pm 0,89$ & $32,870 \pm 0,851$ & $-0,3$ \\
\hline Постпрандіальна глікемія, ммоль/л & $10,47 \pm 0,43$ & $9,70 \pm 0,26$ & $-1,77^{*}$ \\
\hline HbAlc, \% & $9,11 \pm 0,26$ & $8,71 \pm 0,13$ & $-1,05^{*}$ \\
\hline
\end{tabular}

Примітка. Різниця між групами до і після лікування вірогідна: * - p<0,05.

таблиця 2. Динаміка досліджуваних показників на початку лікування і через 12 тижнів після приймання препарату «Воксид» у групі пацієнтів із ЦД 2 типу, з синдромом діабетичної стопи

\begin{tabular}{|l|c|c|c|}
\hline \multicolumn{1}{|c|}{ Показник } & На початку дослідження & Через 12 тижнів & 3міни \\
\hline Маса тіла, кг & $98,42 \pm 4,42$ & $98,28 \pm 4,26$ & $-0,06$ \\
\hline IMT, кг/м & $35,66 \pm 1,26$ & $35,15 \pm 1,23$ & $-1,51$ \\
\hline Постпрандіальна глікемія, ммоль/л & $10,40 \pm 0,40$ & $8,46 \pm 0,25$ & $-1,94^{*}$ \\
\hline HbAlc, \% & $8,41 \pm 0,32$ & $7,46 \pm 0,29$ & $-0,87^{* *}$ \\
\hline
\end{tabular}

Примітки: різниця між групами до і після лікування вірогідна: * - p<0,01; ** - p<0,05.

явища. 3 огляду на ефективність препарату «Воксид» щодо корекції постпрандіальної гіперглікемії і, як результат, зменшення рівня HbAlc, а також зменшення маси тіла на тлі його приймання, навіть у поєднанні $з$ інсулінами, він був рекомендований для подальшого лікування всім пацієнтам даної групи.

Висновки. 1. Препарат «Воксид», що належить до групи інгібіторів альфа-глюкозидази можна рекомендувати для комбінованої терапії пацієнтам на цукровий діабет 2 типу, який ускладнений синдромом діабетичної стопи.

\section{ЛITEPATУРА}

1. Уніфікований клінічний протокол первинної та вторинної (спеціалізованої) медичної допомоги при цукровому діабеті 2 типу, затверджений наказом Міністерства охорони здоров'я України від 21.12.2012 р. № 1118.

2. Діагностика та лікування метаболічного синдрому, цукрового діабету, предіабету та серцево-судинних захворювань. Методичні рекомендації робочої групи з проблем метаболічного синдрому, цукрового діабету, предіабету та серцево-судинних захворювань Української асоціації кардіологів і Української асоціації ендокринологів. - К., 2009. - 42 с.

3. Паньків В. І. Американська діабетична асоціація: стандарти медичної допомоги хворим на цукровий діабет / В. І. Паньків // Міжнародний ендокринологічний журнал. - 2015. - № 2 (14). - С. 34-38.
2. При поєднанні воксиду та інсулінотерапії у хворих на ЦД 2 типу покращується глікемічний контроль шляхом зниження постпрандіальної глікемії та рівня глікованого гемоглобіну.

3. Зниження маси тіла та покращення глікемічного контролю дозволить хворим на ЦД 2 типу з синдромом діабетичної стопи відтермінувати прогресування мікро- та макросудинних ускладнень.

Перспективи подальших досліджень полягають у вивченні впливу препаратів групи альфа-глюкозидази на профілактику хронічних судинних ускладнень у хворих на цукровий діабет 2 типу.

4. Паньків В. І. Ефективність застосування ліраглутиду у хворих на цукровий діабет 2-го типу з ожирінням в реальній клінічній практиці / В. І. Паньків // Міжнародний ендокринологічний журнал. - 2014. - № 6 (62). - С. 91-101.

5. Паньків В. І. Нові терапевтичні можливості управління цукровим діабетом 2-го типу: досвід використання воглібозу / В. І. Паньків // Міжнародний ендокринологічний журнал. - 2014. - № 6 (62). - С. 51-54.

6. Ведение пациентов с сахарным диабетом. Рекомендации Американской ассоциации по изучению диабета (2010) // Рациональная фармакотерапия. - 2010. № 2 (15). - С. 69-76.

7. Маньковский Б. Н. Метаболический синдром: существует ли решение проблемы? / Б. Н. Маньковский, Е. И. Митченко, Т. Ф. Татарчук // Медицинские аспекты здоровья женщины. - 2007. - № 3. - С. 4-12. 